Vol. 7 (1998): 13-19.

\title{
Effect of the environment inside and outside the cage on the activity and behaviour test performance of silver foxes
}

\author{
Teppo Rekilä, Leena Ahola, Jaakko Mononen, Mikko Harri \\ University of Kuopio, Department of Applied Zoology and Veterinary Medicine, PO Box 1627, \\ FIN-70211 Kuopio, Finland, e-mail: rekila@uku.fi
}

\begin{abstract}
On the basis of daily activity in the home cage and the open field test the effect of the internal design and location of cages on the behaviour of silver foxes (Vulpes vulpes) during a growth period was evaluated. The inclusion of platforms in cages increased the daytime activity of silver foxes in their home cage, but the inclusion of nest boxes did not. Silver foxes housed at the front of the animal barn were less active during the working day and more active in the evening than were animals housed at the rear. The results of the open field test did not differ significantly between animals housed in cages differing in design. This study demonstrates that the behaviour of silver foxes was only minimally affected by the interior environment of the cage, and that attempts to improve housing design should also take the environment outside the cage into account.
\end{abstract}

Key words: cage environment, circadian rhythm, farm foxes, open field behaviour

\section{Introduction}

It is generally believed that the environment in which confined farm animals live comprises only the space limited by the enclosure walls. Accordingly, recommendations and suggestions for improved housing systems usually focus on the cage interior. This holds true for farmed foxes too (European Convention 1991).

As a basic improvement, the European Convention (1991) requires the housing systems used in fox farming to be furnished with nest boxes and platforms. The use of these furnishings varies greatly, depending on their design, the spe- cies of fox and the preference shown by individual animals (Mononen 1996). Silver but not blue foxes, have a clear-cut preference for cages with nest boxes (Mononen et al. 1996). Silver foxes housed in double fox cages $(2.0 \mathrm{~m} \times 1.2 \mathrm{~m} \times 0.8 \mathrm{~m})$ with three different nest boxes and a platform had a lower base level of blood cortisol and were faster to proceed in the open field than were animals housed in traditional cages. Moreover, fewer animals in the enriched environment were fearful towards humans and more reacted defensively towards them (Jeppesen and Pedersen 1991). Another study, in contrast, failed to show any effect of nest box or platform (Harri et al. 1995). Moreover, Harri et al. (1995) found that age and 


\section{AGRICULTURAL AND FOOD SCIENCE IN FINLAND}

Rekilä, T. et al. The activity and behaviour test performance of silver foxes

season had a greater effect on the reaction towards humans and on open field behaviour in both blue and silver foxes than had access to a platform or nest box throughout the year. In addition, our previous study with blue foxes demonstrated that the actual environment in which the farmed foxes lived was far larger than merely the cage interior (Rekilä et al. 1996). The inclusion of nest boxes or platforms in the cage affected the behaviour of the animal to a lesser extent than did the location of the animal's cage within the row of cages, i.e. the environment outside the cage itself. The animals housed in the front section of the barn were nearest the door and thus exposed to more interaction with people coming in. This emphasizes the fact that, under normal farm conditions, animals in different parts of the farm may experience considerable differences in sensory input. This effect has not usually been taken into account.

Red foxes are said to be nocturnal and crepuscular in the wild (Harris and Lloyd 1991). Under farm conditions, however, over $50 \%$ of the daily activity of blue foxes occurred during daylight (Rekilä et al. 1996). One would expect that farmed silver foxes too, would be active during the photophase, when people are active on the farm.

In our study, juvenile silver foxes were housed during the autumn in three types of cage: a standard cage without any structural additions, a cage with a platform and a cage with a nest box. We evaluated the effects of the structural additions and the location of the cage on the behaviour of the foxes (see Rekilä et al. 1996).

\section{Material and methods}

\section{Animal housing and management}

The experiment was conducted between September and December at the Fur Animal Research Station of the University of Kuopio. All the behavioural tests were carried out in November.
Silver fox cubs (43) of both sexes from 14 litters were housed singly in standard fox cages $(1.15 \mathrm{~m} \times 1.05 \mathrm{~m} \times 0.70 \mathrm{~m}, \mathrm{LxW} \times \mathrm{H})$ in an unheated animal barn with eight rows of cages. A row of windows ( $1 \times 1.2 \mathrm{~m}, \mathrm{WxH}, 2.4 \mathrm{~m}$ apart) on both long sides exposed the foxes to the natural photoperiod. In addition, electric lights were automatically switched on at sunrise and off at sunset. Siblings were randomly allocated into three groups. Fifteen ( 8 males, 7 females) cages were provided with a wooden platform $(1.05 \mathrm{~m} \mathrm{x}$ $0.24 \mathrm{~m}$ ) hung approximately $0.25 \mathrm{~m}$ below the cage ceiling, and 15 ( 7 males, 8 females) cages were provided with a standard breeding box with a main chamber $(0.41 \mathrm{~m} \times 0.40 \mathrm{~m} \times 0.35 \mathrm{~m}$, Lx$\mathrm{WxH})$ and a smaller anteroom. Thirteen ( 7 males, 6 females) control animals had neither boxes nor platforms. The groups were positioned in the two middle cage rows of the barn, each row consisting of 22 cages. In each of the two rows, the different cage types were in the sequence: nest box cage, platform cage, empty cage, nest box cage, etc. (see Rekilä et al. 1996). The animals were hand-fed twice daily; between 0900 and 1000 and between 1300 and 1400 .

\section{Open field test}

The open field arena consisted of a closed wiremesh runway $(5.0 \mathrm{~m} \times 1.05 \mathrm{~m} \times 0.7 \mathrm{~m}, \mathrm{LxWxH})$ shielded by opaque walls. Before the test, about $300 \mathrm{~g}$ of fresh feed was placed at one end of the runway. Animals were deprived of food for 24 hours before the test.

Foxes in their home cage were captured with neck tongs and carried in an opaque start box $(0.55 \mathrm{~m} \times 0.29 \mathrm{~m} \times 0.41 \mathrm{~m}, \mathrm{LxWxH})$ to the open field arena. The box was then connected to the end of the runway opposite the feed. After the foxes had undergone a calming period of $1 \mathrm{~min}$, the sliding door of the box was opened by remote control. If a fox was still inside the start box $1 \mathrm{~min}$ after the sliding door was opened, it was gently forced into the runway. The observer then left the shed. Each fox was video-recorded for the whole $5 \mathrm{~min}$ experimental period (video 
Vol. 7 (1998): 13-19.

Table 1. Effect of a nest box or platform on behavioural parameters in silver foxes.

\begin{tabular}{lllll}
\hline & Nest box & Platform & Control & $\mathrm{P}^{\mathrm{l}}$ \\
\hline Open field test & & & & \\
Out (yes/no) & $5 / 10$ & $4 / 10$ & $4 / 9$ & NS \\
End (yes/no) & $15 / 0$ & $14 / 0$ & $13 / 0$ & NS \\
Smell (yes/no) & $2 / 13$ & $2 / 12$ & $2 / 11$ & NS \\
Eat (yes/no) & $2 / 13$ & $1 / 13$ & $2 / 11$ & NS \\
Rearings, counts/5 min & $2.1 \pm 2.2$ & $4.0 \pm 5.0$ & $3.2 \pm 4.3$ & NS \\
Total activity, counts/ 5 min & $140 \pm 43$ & $163 \pm 72$ & $156 \pm 89$ & NS \\
& & & & \\
In-cage tests & & & & \\
Active time, \%/ 24h & $38^{\mathrm{a}} \pm 5$ & $42^{\mathrm{b}} \pm 3$ & $38^{\mathrm{a}} \pm 4$ & $<0.05$ \\
\hline
\end{tabular}

${ }^{1} \chi^{2}$ test; ANCOVA (cage location as covariate) test for activity in open field and in home cage.

${ }^{a, b}$ Groups with common superscript do not differ.

camera: Philips LDH 460, video-recorder: Ikegami TVR-625).

The open field arena was divided into 9 subfields of equal size on the video screen. We analysed the activity (number of visits) of the animal spatially for each of the 9 subfields and temporally for each of the $5 \mathrm{~min}$ in the open field. As the spatial and temporal distribution of the activity did not provide any additional information, only data on the total number of visits (activity) (9 fields x $5 \mathrm{~min}$ ) are presented. The occurrence of the following behaviours was also recorded: animal exits start box (out), animal enters last field (end), animal smells food (smell), animal eats food (eat), animal rears up to touch the cage wall (rearings).

\section{In-cage tests}

The behaviour of each individual in its home cage was video-recorded during one random 24hour period at the beginning of October with a system described by Mononen et al. (1996). The behaviour of the animals was analysed from the videotapes using the instantaneous sampling method with a 5 min sampling interval (Martin and Bateson 1993). The variables measured in the home cage were: activity on the wire mesh floor, resting on the wire mesh floor, activity on the roof of the nest box or on the platform, rest- ing on the roof of the nest box or on the platform, and in the nest box. Activity in the home cage (Table 1 and 2) included all activities: activity on the wire mesh floor, activity on the roof of the nest box and activity on the platform. All activities are expressed as a percentage of the 24-hour period.

\section{Statistics}

The results are presented as mean \pm standard deviation, median (MD) or as numbers of individuals. When differences between housing conditions were tested, the $\chi^{2}$ test was employed for non-parametric data. Differences in open field activity and activity in the home cage between housing conditions and between sexes were tested by ANCOVA (cage location as covariate). The Spearman correlation coefficient was used to measure the effect of cage locations on the number of rearings, on the activity of the foxes in the open field test and on activity in the home cage. Associations between other open field parameters and cage locations were measured by logistic regression. Differences in activity in the home cage for each hour of the day between the front and the rear cages and between housing conditions were measured by the Mann-Whitney U-test and Kruskal-Wallis one-way ANOVA, respectively. To test for the effect of cage 
Rekilä, T. et al. The activity and behaviour test performance of silver foxes

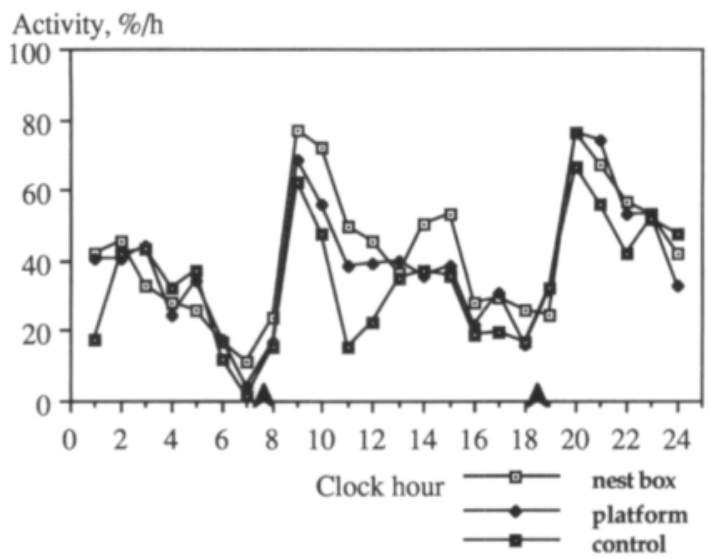

Fig. 1. Intensity and circadian rhythm of activity in the home cage of silver foxes housed in cages with different furnishings. Sunrise and sunset are marked with arrows. No differences were observed in hourly activity between different cage designs (Kruskal-Wallis one-way ANOVA, $\mathrm{P}>0.05$ ).

location on the circadian rhythm of activity, the first 11 cages in the row were classified as front cages and the remaining 11 as rear cages. The Pearson correlation coefficient was calculated to test for an association between the time spent inside the nest box or on the platform and the behaviour in the home cage or in the open field test.

\section{Results}

The sex of the animals had no influence on behaviour either in the open field test or in the home cage $(\mathrm{P}>0.05)$. Moreover, there was no interaction between the effects of sex and inclusions on behaviour $(\mathrm{P}>0.05)$. The data on both sexes are therefore pooled in all results shown.

\section{Circadian activity}

The silver foxes showed a clear circadian rhythm, with two major activity peaks (Figs 1 and 2), one

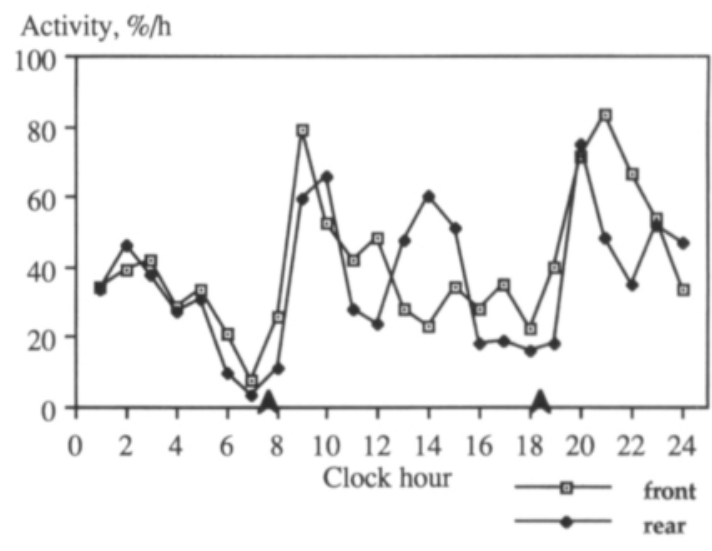

Fig. 2. Intensity and circadian rhythm of activity in the home cages of silver foxes housed in the front and rear of the barn. Sunrise and sunset are marked with arrows. Differences between front cages and rear cages were observed at 0900 and 1200 and at 1300, 1400, 2100 and 2200. (MannWhitney U-test, $\mathrm{P}<0.05$ ).

starting at sunrise and the other at sunset. The dark (1900-0800) and light (0800-1900) phases of the day lasted 11 and 13 hours, and consisted of $45.5 \pm 13.5 \%$ and $54.5 \pm 13.5 \%$ of daily activity, respectively.

\section{Effect of nest box and platform}

Animals with platforms displayed a higher activity level in their home cages than did control animals or animals with nest boxes (Table 1), when adjusted for the effect of cage location by ANCOVA. This difference was evident only during the working day $(0800-1600)$. No difference in activity level was found between the nest box and control groups. Neither nest box nor platform had any other effect on the behaviour of the foxes in the open field test.

\section{Effect of cage location}

A positive correlation was found between cage location and activity in the home cage during the whole day (Spearman $\mathrm{r}=0.32, \mathrm{P}<0.05$ ) and dur- 


\section{AGRICULTURAL AND FOOD SCIENCE IN FINLAND}

Vol. 7 (1998): 13-19.

ing the working day (0800-1600, Spearman $\mathrm{r}=0.53, \mathrm{P}<0.001)$. In contrast, a negative correlation was observed between cage location and activity in the home cage during evening hours (1600-2400, Spearman $\mathrm{r}=-0.36, \mathrm{P}<0.05)$. The same was observed in hourly activity. No effects of cage locations on number of rearings or activity in the open field were found.

\section{Use of nest box and platform}

Foxes living in cages with nest boxes used the roofs of the boxes for active behaviour for $16 \pm$ $7 \%(\mathrm{MD}=19)$ and for resting for $33 \pm 23 \%$ (MD $=44)$ of the day. In addition, they spent $9 \pm 11 \%$ $(M D=6)$ of the time inside the nest boxes. The foxes living in cages with platforms used the platforms for activity an average of $13 \pm 6 \%$ (MD $=14)$ and for resting $18 \pm 19 \%(M D=7)$ of the day. There was no correlation between the time spent in the nest box or on the platform and activity either in the home cage $(\mathrm{P}>0.05)$ or in the open field test $(\mathrm{P}>0.05)$.

\section{Discussion}

The silver foxes displayed a clear circadian rhythm, with two activity peaks: at sunrise and at sunset. The activity of the foxes was not therefore synchronized with the natural photoperiod, as the morning peak coincided with an increase in illumination and the evening peak with a decrease. As a result, about half of the foxes' total daily activity occurred during the photophase and half during the scotophase, as was also found for blue foxes (Rekilä et al. 1996). Wild red foxes are said to be nocturnal and crepuscular (Harris and Lloyd 1991); so are captive red foxes (Tembrock 1957) and farmed silver foxes (Kaleta 1991). The second activity peak in our study, which was most probably caused by sunset, fits this nocturnal activity pattern. In nocturnal species, such as laboratory rats (Kersten et al. 1980), the morning activity typically occurs at the end of the scotophase, not after it. At the time of year that we measured activity, sunrise coincided with the start of the working day. It is possible that farmed foxes postponed the start of their morning activity peak, with human activity acting as the zeitgeber. The main activity in the morning was feeding, which took place at the time the highest activity was observed. The second meal was delivered at 1400 , when the activity of the foxes in the rear part of the row increased slightly. Possibly the animals in the rear were less exposed to humans and so were more excited by the afternoon feeding than were the animals in the front, who were continuously exposed to human activity. Increased activity during feed delivery can be considered as food anticipatory activity.

Our findings show that the circadian rhythm of silver foxes is probably synchronized with both the photophase and human activity. In comparison, the circadian rhythm of farmed blue foxes was not strictly synchronized with either human activity or the photophase (Rekilä et al. 1996). These results emphasize the great flexibility of the natural circadian rhythm in both fox species.

The European Convention (1991) recommendations assume that nest boxes and platforms enrich a barren cage. Recent studies have shown that silver foxes do prefer cages with nest boxes (Mononen et al. 1996). In addition, silver foxes housed in cages furnished with three different nest boxes and a platform had a lower base level of eosinophils, a higher base level of lymphocytes, and a lower base level of cortisol than had animals housed in traditional cages (Jeppesen and Pedersen 1991). They were also more active in the open field and less fearful towards humans in two tests involving human proximity. However, in the present study the behaviour of silver foxes was only marginally affected by the recommended enrichments of the cage interior. The inclusion of platforms increased the activity of animals in their home cages, in comparison with animals living in standard wire mesh cages or cages provided with 
Rekilä, T. et al. The activity and behaviour test performance of silver foxes

nest boxes. However, this was seen only during the working day. This result confirms the different role of nest boxes and platforms found by Mononen (1996). Nest boxes function as both a hiding and a resting place for foxes, whereas platforms act as an observation place, and observation is active behaviour with a high arousal level. Furnishing cages with nest boxes or platforms did not increase the activity of silver foxes in the open field as it did in the study of Jeppesen and Pedersen (1991), possibly because the foxes in Jeppesen and Pedersen's (1991) study spent 2 years in enriched cages before the tests were carried out as against 2 months in our study. On the other hand, the provision of both nest boxes and platforms increased the activity of blue foxes in the home cage during evening hours (Rekilä et al. 1996).

Our present findings, together with those of previous studies (Mononen et al. 1993, Pedersen and Jeppesen 1993, Korhonen and Niemelä 1994a, b, Mononen et al. 1995), indicate that silver foxes do use the furnishings in their cages. However, as shown by Harri et al. (1995), the furnishing did not result in any changes in foxes' temperament that might be revealed in open field or home cage behaviour.

We found earlier that the location of the cage in the row induced greater changes in the behaviour of blue foxes than did the furnishings inside the cage (Rekilä et al. 1996). The animals nearest the door were more active in both their home cages and in the open field test than were those towards the rear of the barn. The present study demonstrated that the environment outside the cage also had an effect on the activity of foxes in their home cage. Animals housed in the front of barn were least active in their home cage during the afternoon hours. In the evening and, to a lesser extent, in the morning, the situation was reversed, and animals housed in the front were the most active. The high activity of foxes in rear cages during the working day could be explained by the fact that the furnishings of the foxes' own and/or neighbouring cages partially obstructed their view of the surroundings, the more so in the rear section of the barn. It has previously been shown that both silver and blue foxes prefer an unobstructed view from their cages (Mononen et al. 1996).

In Rekilä et al. (1996), we attributed the difference in behaviour between blue foxes living in the front and in the rear of the cage row to the different amounts of sensory stimuli to which they were exposed. The animals that lived in the front of the animal barn were nearest the door and thus subjected to greater interaction with the people moving around on the farm. The same explanation can be applied to our present results. Farmed foxes are mostly housed in open 2-row sheds and so can see further than would be possible inside a closed barn. On the other hand, the amount of stimuli may also vary greatly between different parts of a traditional farm with sheds.

The present study with silver foxes supports the conclusions of a previous study with blue foxes (Rekilä et al. 1996), namely, that (i) the actual environment in which the farmed fox lives is larger than the cage interior itself and (ii) attempts to improve housing design should also take the environment outside the cage into account.

Acknowledgements. We thank Matti Tengvall for taking care of the animals and Harri Nurmela for technical assistance. The study was financed by the Research Council for Agriculture and Forestry (Academy of Finland).

\section{References}

European Convention 1991. European Convention for the protection of animals kept for farming purposes. Strasbourg 1976, ETS 87. Recommendation concerning fur animals, 25 June 1991. $19 \mathrm{p}$.
Harri, M., Rekilä, T. \& Mononen, J. 1995. Factor analysis of behavioural tests in farmed silver and blue foxes. Applied Animal Behaviour Science 42: 217-230.

Harris, S. \& Lloyd, H.G. 1991. Fox Vulpes vulpes. In: 
Vol. 7 (1998): 13-19.

Corbet, B.\& Harris, S. (eds.). The handbook of British mammals. 3rd edition. Oxford: Blackwell Scientific Publications. p. 351-367.

Jeppesen, L.L. \& Pedersen, V. 1991. Effects of wholeyear nest boxes on cortisol, circulating leucosytes, exploration and agonistic behaviour in silver foxes. Behavioural Processes 25: 171-177.

Kaleta, T. 1991. Investigations concerning the behaviour of farm silver fox (Vulpes vulpes L.) and an attempt to utilize the results for breeding and keeping improvement. Treatises and Monographs No. 154, Warsaw Agricultural University, Warsaw.

Kersten, A., Stubbe, J.H. \& Spiteri, N.J. 1980. Meal patterning of rats with changes in day length and food availability. Physiology and Behavior 25: 953-958.

Korhonen, H. \& Niemelă, P. 1994a. Use of various platforms and nest box by farmed blue and silver foxes. Nordiske Jordbrugsforskeres Forening, Seminar nr. 253, 28-30 September 1994, Skörping, Denmark. $23 \mathrm{p}$.

- \& Niemelā, P. 1994b. Preferences of silver and blue foxes for farm cage and pen. Nordiske Jordbrugsforskeres Forening, Seminar nr. 253, 28-30 September 1994, Skörping, Denmark. 15 p.

Martin, P. \& Bateson, P. 1993. Measuring behaviour: An introductory guide. 2nd ed. Cambridge University Press, Cambridge. 222 p.

Mononen, J. 1996. Resting platforms and nest boxes for farmed blue foxes (Alopex lagopus) and silver foxes (Vulpes vulpes): the extent of use, reasons for use and welfare effects. Kuopio University Publications C. Natural and Environmental Sciences 52. 62 p.

- , Harri, M. \& Rekilä, T. 1996. Comparison of preferences of farmed silver and blue foxes for cages with and without a nest box. Acta Agriculturøe Scandinavica, Section A, Animal Science 46: 117-124.

- , Harri, M., Rekilä, T., Korhonen, H. \& Niemelă, P. 1995. Use of nest boxes by young farmed silver foxes ( $V u l-$ pes vulpes) in autumn. Applied Animal Behaviour Science 43: 213-221.

- , Harri, M., Rouvinen, K. \& Niemelä, P. 1993. The use of resting platforms by young silver foxes (Vulpes vulpes). Applied Animal Behaviour Science 38: $301-$ 310.

Pedersen, V. \& Jeppesen, L.L. 1993. Daytime use of various types of whole-year shelters in farmed silver foxes and blue foxes. Applied Animal Behaviour Science 36: 259-273.

Rekilä, T., Mononen, J. \& Harri, M. 1996. Effect of inside-cage and outside-cage environment on behaviour test performance of blue foxes (Alopex lagopus). Acta Agriculturœe Scandinavica, Section A, Animal Science 46: 247-252.

Tembrock, G. 1957. Das Verhalten des Rotfuches. Handbuch der Zoologie 8: 1-20.

\title{
SELOSTUS
}

\section{Kasvatushäkin ympäristön vaikutus hopeakettujen käyttäytymiseen}

\author{
Teppo Rekilä, Leena Ahola, Jaakko Mononen ja Mikko Harri \\ Kuopion yliopisto
}

Tutkimuksessa selvitettiin kasvatushäkin ympäristön vaikutusta hopeakettujen käyttäytymiseen niiden omassa häkissä ja avokenttätestissä. Hyllyn lisääminen häkin sisälle lisäsi hopeakettujen vuorokausiaktiivisuutta. Sen sijaan pesäkopin tarjoaminen ei lisännyt aktiivisuutta. Eläinhallin ulko-oven läheisyyteen sijoitetut hopeaketut olivat työpäivän aikaan passiivisempia ja illan aikana aktiivisempia kuin hallin ta- kaosaan sijoitetut. Avokenttäkäyttäytyminen ei riippunut häkin sijainnista hallissa, eikä myöskään häkin sisällöstä. Tulosten perusteella voidaan todeta, että häkki tai häkin sisältö vaikuttivat hopeakettujen käyttäytymiseen hyvin vähän. Häkin ympäristö tulee ottaa nykyistä enemmän huomioon, kun hopeakettujen kasvatusympäristöä pyritään parantamaan. 